\title{
SYNTHESIS OF A PERHYDROINDOLIC ANALOG OF KAINIC ACID
}

\author{
Mathieu Danel, Akram Hijazi, Roland Barret* \\ Laboratoire de Chimie Therapeutique, EA 3741, Faculte de Pharmacie, Universite Claude \\ Bernard, 8 Avenue Rockefeller, F69373 Lyon Cedex 08
}

\begin{abstract}
Synthesis of perhydroindolyl-2-carboxy-3-acetic acid, a strained analog of kainic acid, is described. This compound was obtained in 7 steps by the use of the Barco procedure from nitrocyclohexene.
\end{abstract}

\section{Introduction}

In the recent years there has been a growing interest in the L-glutamate receptors in the central nervous system. This neurotransmitter plays a role of utmost importance in many physiological processes such as neuronal plasticity, memory and learning (1) but an excessive L-glutamate release can result in neuronal cell death by excitotocity.

Among the different sub-types of receptors of L-glutamate (AMPA, kainic acid, MNDA, metabotropic) (2) kainic acid 1 is an agonist of kainic acid receptor and kaitocephalin 2 (3) is an antagonist but the selectivity is low and these compounds have affinity in particular for the AMPA receptor.

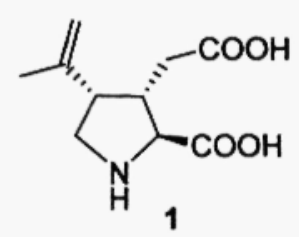<smiles>N[C@@H](C(=O)O)[C@H](O)C1(C(=O)O)CCC(C[C@H](NC(=O)c2cc(Cl)c(O)c(Cl)c2)C(=O)O)N1</smiles><smiles>O=C(O)C[C@@H]1C(C(=O)O)NC2CCCCC21</smiles>

With the aim to obtain a selective affinity for the kainic acid receptor, we had projected to synthesize the analog 3 of kainic acid.

\section{Result and discussion :}

The precursor 5 of 4 is obtained by the use of Barco's process (4) with two Michael reactions with 1-nitro-cyclohexene and the amino-alcohol-ester 4 . Some chemical modifications of 5 give 3. 


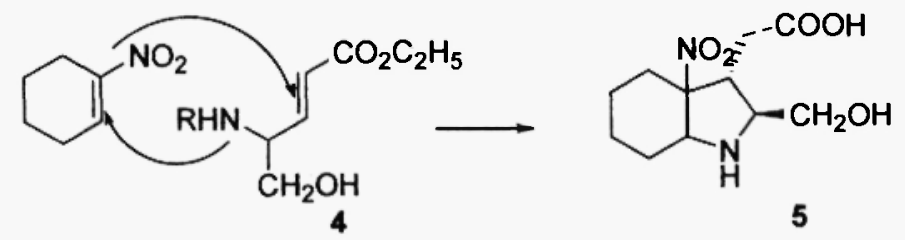

-Synthesis of the amino-alcohol-ester 4

The ester 4 was obtained from serine in seven steps.

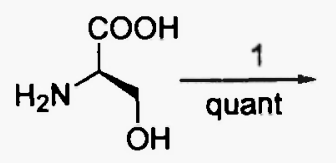<smiles>COC(=O)C(N)CO</smiles>

6<smiles>COC(=O)C(CO)NCc1ccccc1</smiles>

7
8<smiles>CCOCC(C(=O)OC)N(Cc1ccccc1)C(=O)OC</smiles>

\section{9}

Scheme $1-1-\mathrm{CH}_{3} \mathrm{OH}, \mathrm{CH}_{3} \mathrm{COCl}, 0^{\circ} \mathrm{C}$, then reflux for $3 \mathrm{~h} .2-\mathrm{a}-\mathrm{Et}_{3} \mathrm{~N}, \mathrm{C}_{6} \mathrm{H}_{5} \mathrm{CHO}-\mathrm{b}-$ $\mathrm{NaBH}_{4}$. 3-(Boc) ${ }_{2} \mathrm{O}, \mathrm{Et}_{3} \mathrm{~N}$, THF. 4- TBDMSiCl, $\mathrm{Et}_{3} \mathrm{~N}, \mathrm{DMAP}, \mathrm{CH}_{2} \mathrm{Cl}_{2}$.

D-serine gave the ester 6 as hydrochloride quantitatively. After reductive alkylation ( $\mathrm{PhCHO}$ $\mathrm{NaBH}_{4}$ ) the secondary amine 7 was transformed in the carbamate 8 and then alcohol function was protected as silyl ether 9.

To obtain aldehyde function, ester 9 was reduced in alcohol by the use of lithium aluminium hydride at $-50^{\circ} \mathrm{C}$ and then oxidized in aldehyde by the Swern reaction. During the reduction step a few quantity of aldehyde 11 was isolated.

The aldehyde 11 was not purified and directly reacted with (carboethoxymethylene) triphenylphosphorane to give 12 (trans isomer) in a good yield.

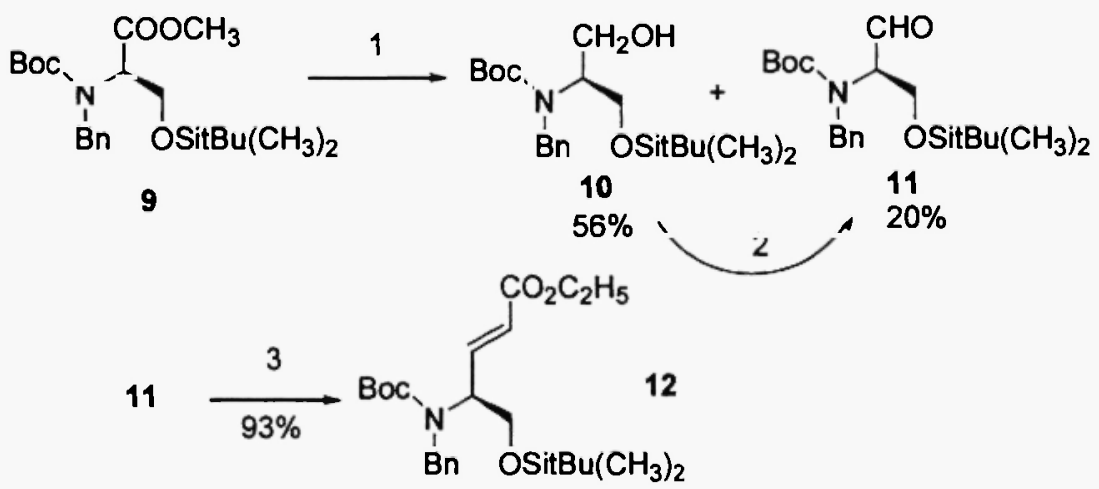


Scheme 2 - 1- $\mathrm{LiAlH}_{4}$, THF. 2- $\mathrm{Et}_{3} \mathrm{~N}$, DMSO, $(\mathrm{COCl})_{2}$. 3- $\left(\mathrm{C}_{6} \mathrm{H}_{5}\right)_{3} \mathrm{PCHCO}_{2} \mathrm{C}_{2} \mathrm{H}_{5}$, $\mathrm{CH}_{2} \mathrm{CI}_{2}$.

The aldehyde obtained during the reduction step gave 12 to increase yield. Thus 12 was obtained with a good yield ( $93 \%$ from 9 ). At last, the protective group was cleaved with trifluoroacetic acid to give 4.<smiles>CCOCC(C=CC(=O)OCC)N(Cc1ccccc1)C(=O)OCC</smiles>

12<smiles>CCOC(=O)/C=C/C(CO)Nc1ccccc1</smiles>

4

Scheme 3- $\mathrm{CF}_{3} \mathrm{CO}_{2} \mathrm{H}, \mathrm{CH}_{2} \mathrm{Cl}_{2}$

The global yield of the synthesis of 4 from serine in 7 steps was $24 \%$.

-Condensation of 4 with 1-nitrocyclohexane.

Nitrocyclohexene and 4 were stirred for seven days at room temperature. After this time, 13 was obtained with a $65 \%$ yield. All modifications of these conditions (time, temperature, solvent....) lead to low yields.

This reaction is a double-Michael addition:

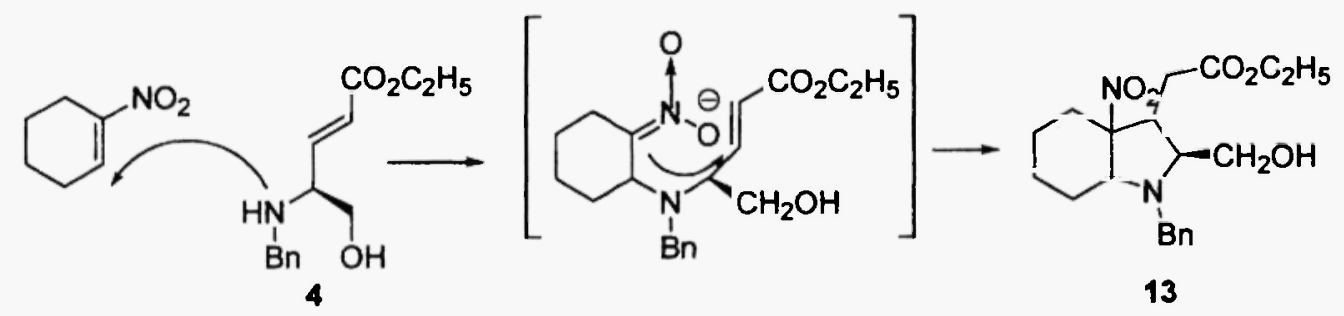

The nitro group was eliminated by reflux into toluene with tributyltin hydride in the presence of catalytic quantity of AIBN to give 14.

Debenzylation succeeded with Pd-C 5\% in alcohol under hydrogen pressure ( 25 bars) on the condition that one or two drops of $10 \%$ hydrochloric acid be added. In the absence of acid no reaction took place.

It's known that in case of amino-alcohol the amino group must be protected with tertbutoxycarbamate function during the oxidation of the alcohol function into acid $(4,5)$; then, after debenzylation and protection of amine with tert-butoxycarbonyl group, the oxidation with PDC gave acid 16. 


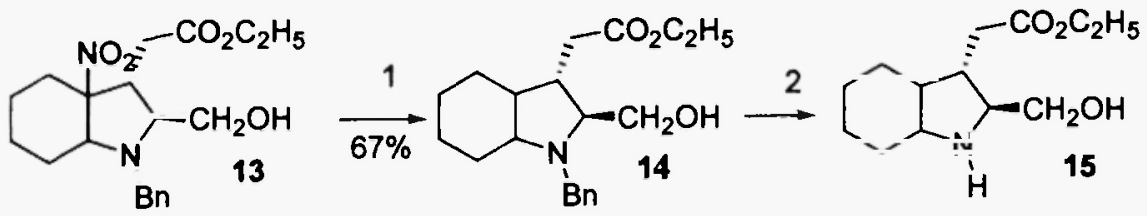

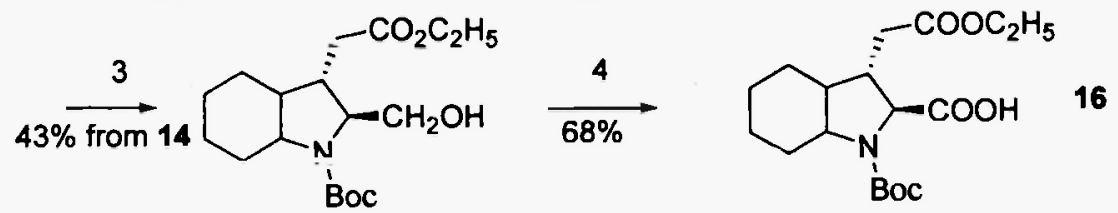

Scheme $4-1-\mathrm{Bu}_{3} \mathrm{SnH}, \mathrm{AIBN}$, toluene, reflux. 2- $\mathrm{H}_{2} 25$ bars, $\mathrm{Pd} . \mathrm{C}, \mathrm{C}_{2} \mathrm{H}_{5} \mathrm{OH}, \mathrm{HCl}$ $10 \% 2$ drops. 3- (Boc) $)_{2} \mathrm{O}, \mathrm{Et}_{3} \mathrm{~N}, \mathrm{THF}$. 4- $\mathrm{PDC}, \mathrm{CH}_{2} \mathrm{Cl}_{2}$.

This acid-ester 16 was hydrolysed by $\mathrm{LiOH}$ and deprotected with trifluoroacetic acid.

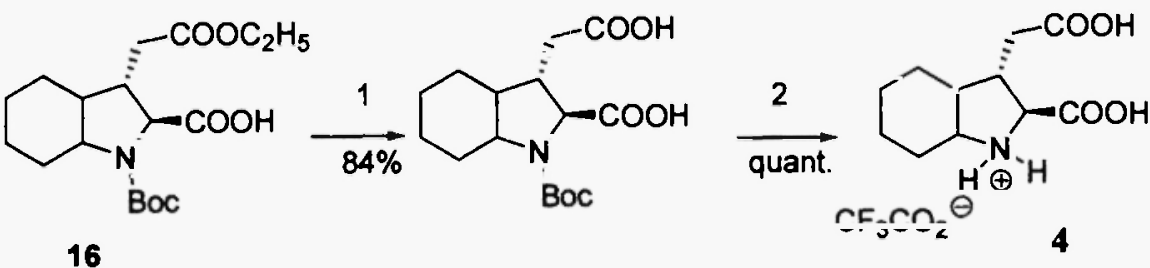

Scheme 4- 1-LiOH, $\mathrm{H}_{2} \mathrm{O}$, THF. 2- $\mathrm{CF}_{3} \mathrm{CO}_{2} \mathrm{H}, \mathrm{CH}_{2} \mathrm{Cl}_{2}$.

\section{Conclusion}

The compound 4 was obtained with a global yield of $11 \%$ from nitrocyclohexene. Now, we synthesize other compounds by this strategy and we have to test these ones with different Lglutamate sub-type receptors

\section{Aknowledgements}

The authors thank ANVAR and EZUS for their financial support.

\section{References}

(1) N.S. Nakanishi, Science 258,31 (1992); Z.A. Bartolotto, Z.I. Bashir, C.H. Davies, G.L. Collingridge, Nature 368, 740 (1994).

(2) M.D. Cunningham, J.W. Ferkany, S.J. Enna, Life Sciences 54, 135 (1994). M. Hollmann, S. Heinemann, Annu. Rev. Neurosc. 17, 31 (1994).

(3) K. Shin-Ya, J.S. Kim, K. Furibata, Y. Hayakawa, H. Seto, Tetrahedron Lett. 38, 7079 (1997). D. Ma, J. Yang, J. Amer. Chem. Soc. 123, 9706 (2001).

(4) A. Barco, S. Benetti, A. Casolari, G.P. Pollini, G. Spalluto, Tetrahedron Lett. 31, 4917 (1990). A. Barco, S. Benetti, G. Spalluto, J. Org. Chem. 57, 6279 (1992).

(5) F.J. Sardina, M.H. Howard, A.M.P. Koshinen, H. Rapoport, J. Org. Chem. 54, 4654 (1989).

(6) Analytical data 4: yellow oil, ${ }^{1} \mathrm{H}-\mathrm{NMR}\left(\mathrm{CDCl}_{3}, 200 \mathrm{MHz}\right) \delta(\mathrm{ppm}): 1.05-2.45(\mathrm{~m}, 9 \mathrm{H}$, $\mathrm{H}-3 \mathrm{a}$ and $\left.\left(\mathrm{CH}_{2}\right)_{4}\right), 2.45-3.00\left(\mathrm{~m}, 3 \mathrm{H}, \mathrm{H}-3, \mathrm{CH}_{2} \mathrm{CO}_{2}\right), 3.80-4.50(\mathrm{~m}, 2 \mathrm{H}, \mathrm{H}-2$ and $\mathrm{H}-7 \mathrm{a})$, 10.16 and $12.01(2 \mathrm{~s}, 4 \mathrm{H}, 2 \mathrm{COOH}, 2 \mathrm{NH})$. $\mathrm{MS}(\mathrm{EI}): 228\left(\mathrm{M}^{+}\right)$.

Received on October 4, 2004 